\title{
Universiteit
}

Leiden

The Netherlands

\section{Renaming the Mexican Codices}

Jansen, M.E.R.G.N.; Pérez Jiménez, G.A.

\section{Citation}

Jansen, M. E. R. G. N., \& Pérez Jiménez, G. A. (2004). Renaming the Mexican Codices. Ancient Mesoamerica, 15, 267-271. Retrieved from https://hdl.handle.net/1887/16354

Version: $\quad$ Not Applicable (or Unknown)

License: $\quad$ Leiden University Non-exclusive license

Downloaded from: https://hdl.handle.net/1887/16354

Note: To cite this publication please use the final published version (if applicable). 


\title{
RENAMING THE MEXICAN CODICES
}

\author{
Maarten Jansen and Gabina Aurora Pérez Jiménez \\ Department of Archaeology and History of Native American Peoples, Faculty of Archaeology, Leiden University, P.O. Box 9515, \\ 2300 RA Leiden, The Netherlands
}

\begin{abstract}
The names of many pictorial manuscripts from ancient Mesoamerica honor collectors, politicians, scholars, or institutions of the "Western" world or the national elite, alien to the people who created them and the region to which they refer. Different usages in designating these codices and lienzos have introduced some confusion in the nomenclature. Here, a new set of names is proposed that is more in conformity with the contents of the documents and closer to the Mesoamerican culture.
\end{abstract}

Many aspects of the Native American world are now formulated and discussed in terms of a national or international metalanguage (Spanish or English). This practice has an alienating effect. The geography of the conquered continent was rebaptized with designations such as New Spain, New Amsterdam, or New York, as well as Mérida, California, or Venezuela. Christian patron saints and republican heroes (such as Washington, Bolivia, Hidalgo, and Morelos) dominate the landscape. Similarly, terms such as "ethnic minorities" or "groups" in "refuge areas" are used to characterize the Native American peoples without taking into account their own perspective. Their faith, with its ancient holy accounts, first was referred to as "superstition" and "witchcraft" by colonial authors, then dubbed "folklore" and "myth" by modern researchers. The main predicament of indigenous peoples today is not one of terminology or representation. Still, the dominant use of foreign languages and conceptualizations contributes to separating them from their cultural heritage. At the same time, the gap between inheritors and investigators widens, with negative consequences for interpretive studies.

This problem is particularly relevant in studies of ancient writing systems and visual arts. Obviously, these scenes and texts have to be interpreted and read in adequate terms, preferably those of the culture and language concerned. Iconographic analysis often has to resort to the use of code names to refer to unknown elements, but, as knowledge proceeds and understanding deepens, these are usually replaced with more appropriate designations. A famous example is the Maya "toothache glyph," now recognized as a sign for accession. The custom of indicating ancient rulers in Ñuu Dzaui (Mixtec) pictorial manuscripts with the signs for "male" and "female" has been superseded by the use of their proper titles, "Lord" (iya) and "Lady" (iyadzehe). The painting of an animated stone, called "Xolotl" or "Ollin figure" by early researchers, has now been identified as the Nuhu, the Earth Spirit, and a composite being, the "turtle-xiuhcoatl-sacrificer," is now read as yahui, the ball of lightning that is a powerful nahual.

E-mail correspondence to: m.e.r.g.n.jansen@arch.leidenuniv.nl
These observations led us to reconsider the names of a group of Mesoamerican pictorial manuscripts, or codices, themselves. ${ }^{1}$ The documents in question often are named for collectors, politicians, scholars, or institutions of the "Western" world or the national elite, far removed from the region from which they originated and to which they refer. Is it not strange that the major religious book of ancient Mesoamerica is known as the Codex Borgia? How would the present-day inhabitants of Nuu Dzaui suspect that the history of the kings and queens who once ruled their towns is registered in books called Codex Bodley or Codex Vindobonensis? Who would think that the dramatic story of the life of a major figure in that history, Iya Nacuaa 'Teyusi Naña' (Lord 8 Deer 'Jaguar Claw'), is told in a manuscript called Codex ColombinoBecker? The proposal of the Mexican scholar Miguel LeónPortilla (1996) to change the name of this last document to Codex Alfonso Caso in honor of its main interpreter is hardly a step forward.

It is time to start using adequate names for these important manuscripts. One might argue that the currently used designations are well established in the scholarly literature and that changing them would bring about confusion, but confusion already exists. First, several manuscripts have more than one name in the literature (e.g., Sánchez Solís/Egerton) or are known by quite different references in the library or museum where they are kept. Moreover, some authors have begun to replace the traditional names with others. Ross Parmenter (1982), for example, successfully renamed the Lienzo Antonio de León the Lienzo of Tlapiltepec. This change is quite justified, as it was based on Parmenter's identification of the document's place of origin. Other alternatives have found less support. Indeed, it is doubtful that Tonalamatl de

\footnotetext{
${ }^{1}$ The census of pictorial documents by John Glass and Donald Robertson (1975) contains codicological data and brief notes about the history of the documents. Our research, which has concentrated on the preColonial religious and historical manuscripts, was supported by Leiden University (Faculty of Archaeology and Center of Non-Western Studies Research School of Asian, African and Amerindian Studies) and received additional grants from the Netherlands Organization for Scientific Research (NWO).
} 
los Pochtecas (León-Portilla 1985) is an adequate characterization of the Codex Fejérváry-Mayer, while names such as "Tepexic Annals" for the Codex Vindobonensis and "Coixtlahuaca Map" for the Fonds Mexicain 20 Manuscript (Brotherston 1995) are based on unconvincing speculations regarding their contents.

As a complex nomenclature is irritating, many scholars oppose the changing of names altogether. But let us not prefer intellectual laziness to the quest for a correct conceptualization. Here a new set of designations is proposed for a number of important screenfold books based on efforts to interpret this unique literary heritage in terms of the civilization that produced them. The new names can be derived from the community of origin, the subject matter, or specific personages associated with the document. Obviously, whenever possible, it is preferable to use terms in the relevant Native American language.

\section{ÑEE ÑUHU: THE CODICES OF ÑUU DZAUI (THE VINDOBONENSIS GROUP)}

The Mixtec people are referred to this way because of the name the Mexicas gave them: Mixtecâ means "Inhabitants of the Land of the Clouds" in Nahuatl. They call themselves Ñu Sau, Nuu Savi, Nuu Dau, or Ñu Daui, according to dialectical variability. The term means "People of the Rain" and appears as N $u u$ Dzavui or $\tilde{N} u u$ Dzahui in the Colonial documents; we write it as $\tilde{N} u u$ Dzaui. The same name is given to the land they inhabit, now generally known as La Mixteca. Its central mountainous area is located in the sovereign state of Oaxaca in southern Mexico and known as the Mixteca Alta, but to the original inhabitants it was Ñuu Dzaui Ñuhu, "Ñuu Dzaui of the Gods." The most important city-state-or, rather, yuvui tayu, "mat and throne"-in the history of this region is Santiago Tilantongo. The combined SpanishChristian and Nahuatl name of this village overshadows its original toponym: N $u$ u Tnoo, "Black Town." An important dictionary of Dzaha Dzaui, the Mixtec language, was published by the Dominican friar Francisco de Alvarado in 1593 (Jansen and Pérez Jiménez 2003). He registered the native term for a pictorial manuscript or codex ñee ñuhu, "sacred (deer)skin." An important corpus of such pictorial chronicles has survived.

- The Codex Bodley is preserved in the Bodleiean Library, Oxford, as MS. Mex. d. 1. The Mexican scholar Alfonso Caso published it as Codex Bodley 2858, in reference to the first known European owner of the manuscript, Sir Thomas Bodley (1545-1613), adding the number from the library catalogue. With its 40 painted pages, the manuscript is a crucial source for the history of Nuu Dzaui Ñuhu (the Mixteca Alta), as a compendium of its major dynasties, with abundant dates. ${ }^{2}$ The obverse side tells the genealogical history of the dynasty of Nuu Tnoo (Tilantongo). The reverse deals with another dynastic line, ending with the ruling family of Ndisi Nuu (Tlaxiaco). The last ruler mentioned on the obverse is Iya Qhcuaa 'Yaha Ndisi Nuu' (Lord 4 Deer 'Eagle of Clear Sight' or 'Eagle of Tlaxiaco'), who reigned in Nuu Tnoo at the time of the Spanish invasion. The last pre-Hispanic ruler on the reverse is Iya Nacuañe 'Dzavui Ndicandii' (Lord 8 Grass 'Rain Sun'), who appears as "Malinaltzin of Tlaxiaco" in central Mexican sources; he is famous because of his resistance to the expanding Mexica empire and his tragic end on the sacrificial stone of the Templo Mayor of Mexico-Tenochtitlan. The Nuu Tnoo ruler Iya Qhcuaa 'Yaha Ndisi Nuu' must have been the

${ }^{2}$ Facsimile edition with commentary: Caso 1960. At present, the Bodleian Library is preparing a photographic reproduction with an introduction by Jansen and Pérez Jiménez. person who ordered the painting of this manuscript and was its first owner. Thus, we might call this document after his calendar name in Dzaha Dzaui: Codex Iya Qhcuaa. However, because the book is not about this ruler alone but about two noble houses-namely, those of Nuu Tnoo (Tilantongo) and Ndisi Nuu (Tlaxiaco)—it seems more appropriate to call it Codex Ñuu Tnoo-Ndisi Nuu, or, if one prefers, the toponyms as they are locally pronounced today, Ñu Toon and Ndijin Nuu.

- The Codex Selden is also preserved in the Bodlean Library, Oxford, and has become known as Ms. Arch. Selden A.2 or Codex Selden 3135. This name is equally derived from its first known European owner, the English scholar John Selden (1584-1654). ${ }^{3}$ The manuscript was painted around 1560 in a completely pre-Colonial style and deals with the history of the dynasty that ruled Añute-that is, Magdalena Jaltepec, in the Valley of Atoco (Nochixtlan), in Ñuu Dzaui Ñuhu, the Mixteca Alta. ${ }^{4}$ Using the criterion of first ownership, we could name the codex after the last ruler portrayed in the manuscript, Iya Sicuañe (Lord 10 Grass), but as the manuscript actually is not about him but contains the whole dynastic history of its community, we prefer the designation Codex Añute.

- The Codex Vindobonensis had already reached Europe by 1521, which implies that it was handed over to the conquistadors at an early date. After an eventful history, it finally landed in what is now the Österreichische Nationalbibliothek in Vienna. Like many other manuscripts in that collection, it is named for the Latin name of Vienna, Vindobona. Locally, of course, it is known as Codex Mexicanus 1. ${ }^{5}$

Originally, the manuscript must have belonged to the ruler or high priest of Nuu Tnoo (Tilantongo) on the eve of the Spanish invasion. The reverse side contains an incomplete and hastily drawn genealogy of the Nuu Tnoo ruling family, similar to that on the obverse side of Codex Ñuu Tnoo-Ndisi Nuu (Bodley). The obverse deals with the sacred account of the creation, starting with the First Primordial Couple in the 'Place Where the Heaven Was'- that is, in a ceremonial center on top of the Kaua Kaandiui near the town of Yuta Tnoho (Santiago Apoala) in Ñuu Dzaui Ñuhu (the Mixteca Alta). It further tells how the founders of different dynasties were born from Iyadzehe Yutnu Nuu, the Great Mother Pochote Tree, in the Sacred Valley of Yuta Tnoho (Apoala). Because of the main theme on the obverse, we prefer to call this manuscript Codex Yuta Tnoho (locally pronounced Yutsa Tohon).

One might wish to use a special designation for the reverse side, as this is clearly a different document, created by another painter. In an earlier publication (Jansen and Pérez Jiménez 2000) we referred to the reverse as Codex Nuu Tnoo, but since then we have changed our opinion. Actually, the well-known place sign of Ñu Tnoo, the Black Frieze, is not present on the reverse. Instead, we find several references to its ceremonial center, the Huahi Andehui, "Temple of Heaven." To avoid confusion with the other, more important manuscript from Ñu Tnoo, the so-called Codex Bodley, we could call it Codex Huahi Andehui. However, it is preferable to keep one name for the whole document (Codex Yuta Tnoho) and distinguish the two sides as "reverse" and "obverse."

- The Codex Zouche-Nuttall (British Museum, London) is named for the nineteenth-century English collector Robert Curzon, Lord Zouche (1810 1873), who bought and owned the manuscript, and the investigator Zelia Nuttall, who in 1902 published a first facsimile reproduction with a commentary. It is a complex document, painted on both sides. The so-

${ }^{3}$ Another document in the same collection is the Selden Roll (Burland and Kutscher 1955), which probably comes from a town in the Valley of Coixtlahuaca, the heartland of the Ngigua people (often referred to as Chochos). Its subject matter is the foundation of a kingdom: priests, as sacred symbols of power from heaven and from a cave, make a fire on a huge central mountain, surrounded by signs for the four directions. We therefore propose to call it the Roll of the New Fire, or Rollo del Fuego Nuevo in Spanish.

${ }^{4}$ Facsimile edition with commentary: Caso 1964. See also Jansen and Pérez Jiménez 2000; Smith 1983, 1994.

${ }^{5}$ Facsimile edition with commentary: Anders, Jansen and Pérez Jiménez 1992a. 
called reverse (which actually was the first side painted) is an unfinished biography of the great king of Nuu Dzaui, Iya Nacuaa 'Teyusi Ñaña' (Lord 8 Deer 'Jaguar Claw'), who, according to the latest calculations, lived from 1063 to 1115 . After the project of painting his life story was abandoned, the so-called obverse side was used as a notebook to copy segments of different dynastic histories, with special attention to the city-states of Chiyo Cahnu (Teozacualco) and Zaachila. ${ }^{6}$ Because of its composite character we call this pictorial manuscript Codex Tonindeye after the Dzaha Dzaui term for "lineage history."

- The Codex Colombino-Becker consists of two fragments. The first is preserved in the codex collection of the Biblioteca Nacional de Antropología in Mexico City and was published as Códice Colombino by the Junta Colombina in 1892 to celebrate the fourth centennial of Columbus's voyage. The second fragment, Codex Becker I, now in the Museum für Völkerkunde in Vienna, was named for a German collector who bought it in Mexico in the late nineteenth century and brought it to Europe. ${ }^{7}$ The rest of the original manuscript is now lost. Research suggests that it was painted (obviously following an older document) on orders of the king of Yucu Dzaa (Tututepec) close to the Pacific Coast, shortly before the Spanish invasion. It tells the life story of the famous warrior and king Iya Nacuaa 'Teyusi Ñaña' (Lord 8 Deer 'Jaguar Claw'). We therefore call it Codex Iya Nacuaa after the calendar name of this protagonist in Dzaha Dzaui. The two fragments that have survived we will call Codex Iya Nacuaa I (Colombino) and Codex Iya Nacuaa II (Becker I). The first remained in Yucu Dzaa at least until the eighteenth century and was heavily annotated with the names of the boundaries of the cacicazgo in alphabetic script. The second was for some time in the possession of a cacique family in Santa María Tindú in the Mixteca Baja before it was transferred in 1852 to the lawyer Pascal Almazán in Puebla as documentation for a lawsuit.

- The Codex Muro is named for Felix Muro, a twentieth-century collector of antiquities in Oaxaca who once owned the manuscript. At present it is in the codex collection of the Biblioteca Nacional de Antropología in Mexico City. It contains a genealogical list of ruling couples of a small city-state, with a short reading of the scenes in Dzaha Dzaui. ${ }^{8}$ The glosses identify the city-state in question as Nuu Naha-that is, San Pedro Cántaros in the Mixteca Alta. The pictorial representation of the main town-Mountain of Head (dzeque) with Open Mouth ( $a$-) - actually may represent San Pedro Cántaros's neighbor San Miguel Adeques (A-dzeque), as argued by Mary Elizabeth Smith (2000). This could mean that the city-state originally had a double capital. We will refer to it using the name of its community of origin as registered in the document itself: Codex Ñuu Naha.

- The Códice Sánchez Solís or Codex Egerton 2895 (British Museum, London) is named for nineteenth-century collectors. It contains the dynasty of a town in the Mixteca Baja, represented as Temple of the Jaguar, most probably Ñuu Ñaña (Cuyotepeji). ${ }^{9}$ We therefore call it Codex Ñuu Ñaña.

- The Codex Becker II, now in the Museum für Völkerkunde in Vienna, is reported to have come from a village near Huexotzingo or Cholula, but it actually contains a lineage history from an unidentified town in the Mixteca Baja. Like the Codex Becker I (the Tindu fragment of Codex Iya Nacuaa), it was named for the German collector Philip J. Becker. We propose to rename it Codex Cochi after the last depicted ruler Iya Cochi 'Cuiñe Sahmi Nuu' (Lord 3 Wind 'Jaguar That Burned the Mexicans'). The beginning of this document, known as the Nochixtlan Fragment, is now in the Museum für Völkerkunde in Hamburg. ${ }^{10}$ Nochixtlan is the place where it was bought. Referring to this particular (section of the)

${ }^{6}$ Facsimile edition with commentary: Anders, Jansen, and Pérez Jiménez $1992 \mathrm{~b}$

${ }^{7}$ Facsimile edition: León-Portilla 1996. For a detailed commentary, see Troike 1974.

${ }^{8}$ It is reproduced and interpreted in Smith 1973. See also Jansen 1994.

${ }^{9}$ See Burland 1965; Jansen 1994; and König 1979.

${ }^{10}$ See Jansen 1994; Nowotny 1961b, 1975; and Smith 1979. document, it is more appropriate to use the first toponym of the story, where the founding father of the dynasty originated-that is, Nuu Naa, the place or time of darkness, and call this part the Nuu Naa Fragment.

- The Codex Tulane actually is not a codex (book) at all but a painted roll that contains the ruling lineages of two of the main city-states of the Mixteca Baja: Toavui (Chila) and Yucu Yusi, (Acatlan) in the southern part of the state of Puebla. ${ }^{11}$ Robbed from the church in Yucu Nindavua (San Martín Huamelulpan) in Nuu Dzaui Ñuhu (the Mixteca Alta), it passed through the hands of the collector Felix Muro and is now in the Latin American Library of Tulane University in New Orleans. Recognizing all the towns it is associated with, we might call it the Roll of Toavui, Yucu Yusi, and Yucu Nindavua. Selecting the most important chapter and central toponym for the sake of brief reference, we propose the designation Roll of Yucu Yusi.

\section{TEOAMOXTLI, THE BOOKS OF WISDOM (THE BORGIA GROUP)}

An important cluster of mostly pre-Colonial manuscripts deals with religious topics, presenting the symbolic associations between segments of time and the power of specific deities, as a base for divination and ritual. The Nahuatl text of Friar Bernardino de Sahagún refers to them using specific terms such as tonalamatl, "paper of the days" (i.e., "calendar"), containing nauallotl, a discourse related to the mysterious powers of the Otherworld. The chronicler Ixtlilxochitl mentions that Huematzin or Huemac, priest and leader of the Toltecs in the Early Postclassic period, composed a large book about divination (good and bad omens) and sacred history, ritual prescriptions, cults, and deities called teoamox$t l i$, "Book (amoxtli) of God (teotl)," or "sacred book." The term is very similar to the Dzaha Dzaui term ñee ñuhu. Reading the description by Ixtlilxochitl, we get the impression that, rather than one specific, single book, a whole group or genre is meant:

\begin{abstract}
Y antes que pase adelante quiero hacer relación de Huematzin, astrólogo, ... el cual antes de morirse juntó todas las historias que tenían los tultecas desde la creación del mundo hasta en aquel tiempo, y las hizo pintar en un libro muy grande, en donde estaba pintado todas sus persecuciones y trabajos, prosperidades y buenos sucesos, reyes y señores, leyes y buen gobierno de sus pasados, sentencias, antiguas y buenos ejemplos, templos, ídolos, sacrificios, ritos y ceremonias que ellos usaban, astrología, filosofía, arquitectura, y demás artes, así buenas como malas, y un resumen de todas las cosas de ciencia y sabiduría, batallas prósperas y adversas y otras muchas cosas y intituló a este libro, llamándolo Teoamoxtli, que bien interpretado quiere decir, diversas cosas de dios y libro divino. Los naturales llaman ahora a la Sagrada Escritura, Teoamoxtli por ser casi del mismo modo [Ixtlilxochitl 1975/77:I:270].
\end{abstract}

Very few examples of such religious books survived the persecution by Spanish missionaries, during which valuable information about their provenience and contents was lost. The books are now collectively named the Codex Borgia Group for the major manuscript. It would be more in accordance with indigenous terminology to designate them the Books of Wisdom. Today, they are known by the names of collectors or libraries. More appropriate names could be derived from special features or diagnostic aspects of their contents. To establish a consistent system of citation to be used in different languages, we might use Nahuatl terms, as

\footnotetext{
${ }^{11}$ See Smith and Parmenter 1991.
} 
most information on Mesoamerican religion was documented in that language. Although it is by no means certain that these manuscripts were painted by speakers of Nahuatl, they probably are part of the Toltec tradition.

- The Codex Borgia (Apostolic Library, Vatican City) is named for Italian Cardinal Stefano Borgia (1731-1804), in whose collection or private museum it was first documented. It contains a special section on rituals in an unidentified ceremonial center dominated by a Temple of Heaven and a Temple of Darkness. ${ }^{12}$ Particularly impressive is the representation of the cult of the Sacred Bundle and the visionary experiences of priests. In religious ecstasy, humans take the form of "vision serpents" with bodies of darkness and masks of the Wind God. This refers to the metaphoric expression yoalli ehecatl, "night and wind" in Nahuatl, which is used to characterize the mysterious condition of the gods. In view of this conceptualization, it seems proper to rename this magnificent work "Book of Night and Wind," or Codex Yoalli Ehecatl.

- The Codex Vaticanus 3773 or Codex Vaticanus B (Apostolic Library, Vatican City) is the "pocket" manual of a day keeper. ${ }^{13}$ Today, it is simply named for the library where it is kept. A more appropriate name, then, is "Book of the Diviner," or Codex Tonalpouhqui.

- The Codex Cospi (University Library, Bologna) was named for the Italian aristocrat Ferdinando Cospi (1606-1686) who received it in 1665 as a Christmas present from Valerio Zani and included it in his private museum in Bologna. ${ }^{14}$ After a standard presentation of the count of 260 days, with their Lords and Ladies of the Nights, the next chapter deals with the "attacks" of the spear-wielding Venus god (Tlahuizcalpantecuhtli) — that is, the possibly negative consequences of the newly rising Venus for different segments of society. These scenes are followed by a chapter that indicates offerings to be made to the four directions. The reverse side of the codex is devoted again to a series of deities threatening to throw their darts, accompanied by altar tables with offerings of counted bundles of leaves, fir needles, or similar materials to invoke their powers and secure protection. Its main theme is similar to that of the Ñahñu (Otomi) or Nahua rituals, with cut-paper figures for protection against "attacks" of spirits (armed with machetes) causing misfortune or disease. We propose the designation "Book of Offerings" or, using the Nahuatl word for "offering," Codex Tlamanalli.

- The Codex Fejérvàry-Mayer (Free Public Museum, Liverpool) combines the names of two European owners: the Hungarian collector Gabriel Fejérváry (1780-1851) and the English antiquarian Joseph Mayer (1803-1886). The manuscript itself gives prominence on its first and last page to the deity of the Smoking Mirror as lord of the days and thirteen-day periods. ${ }^{15}$ This suggests the name "Book of the Smoking Mirror," or Codex Tezcatlipoca.

- The Codex Laud (Misc. 678, Bodleian Library, Oxford) proceeds from the collection of English Archbishop William Laud (1573-1645),

${ }^{12}$ The main breakthrough in the interpretation of this and other members of the Borgia Group is Karl Nowotny's classic monograph Tlacuilolli (Nowotny 1961a). Commentary with facsimile edition: Anders, Jansen, and Reyes García 1993.

${ }^{13}$ Facsimile edition with commentary: Anders and Jansen 1993.

${ }_{15}^{14}$ Facsimile edition with commentary: Anders, Jansen, and Loo 1994.

${ }^{15}$ Facsimile edition with commentary: Anders, Jansen, and Pérez Jiménez 1994. who obtained it in 1636. Its first chapter refers to special influences of the death deities, a reason to call it the "Book of Death," or Codex Mictlan. ${ }^{16}$

- The Codex Porfirio Díaz (Biblioteca Nacional de Antropología, Mexico City) received its name to please the Mexican president of that name during the fourth centennial of Columbus's voyage in 1892. It has been established that the manuscript comes from Yan Yadaa, which translates in Nahuatl as "Tututepetongo" and today is San Francisco Tutepetongo in the Cuicatec Cañada (state of Oaxaca). It combines a historical account of that city-state with a chapter that forms part of the Borgia Group. ${ }^{17}$ After its place of origin, we call it the Codex of Tututepetongo, or, using the original Cuicatec toponym, Codex Yada.

- The Manuscript Fonds Mexicain 20 (Bibliothèque Nationale de France, Paris) is a single painting on deerskin (a copy of which is preserved as Manuscript 21). Divine pairs ("Father and Mother") are situated in the landscapes of the four directions and the center, as is common in the codices of Nuu Dzaui. The scenes are connected with each other through a chevron war band, called уесu in Dzaha Dzaui. As this is the central element in the representation, we propose to rename the document Codex Yecu. ${ }^{18}$

- The Codex Borbonicus, named for the Palais Bourbon in Paris, where it was kept, is a Mexica manuscript clearly related to this group. In its series of year feasts it gives prominence to the role of the high-priest and to the Dark Temple (Tlillan) of his Divine Patron, the Goddess Cihuacoatl. ${ }^{19}$ In the sixteenth century it was sent to the king of Spain and it is mentioned in the list of "Libros de diversas facultades de la testamentaria de Felipe II" (1600) as a "libro en folio mayor, de los caciques de México y de los días que sacrificaban en la semana." Analyzing the glosses, we conclude that the document comes from the area of Xochimilco, but to underline its religious character, we prefer to call it Codex Cihuacoatl.

Our proposals aim to start a discussion among Native Americans interested in their own history and among scholars in general to find a more appropriate, post-Colonial idiom. There is, of course, an arbitrary element in this renaming process. Deities such as Tezcatlipoca and Cihuacoatl are not limited to the manuscripts that we propose to name after them, nor are the references to offerings or death. In fact, all of these codices were in the possession of diviners or tonalpouhque. However, we feel it is imperative to start using names that are more in conformity with the character of the documents and bring us closer to crucial aspects of the Mesoamerican worldview. Further study may lead us to discover even better names. Common reflection, we hope, will result in a generally accepted, recognizable, and dignifying terminology.

\footnotetext{
${ }^{16}$ Facsimile edition with commentary: Anders and Jansen 1994

${ }^{17}$ Facsimile edition with commentary on the historical section: Van Doesburg 2001. Commentary on the religious section: Anders and Jansen 1994.

${ }^{18}$ Color reproduction with commentary: Jansen 1998. 1991.

${ }^{19}$ Facsimile edition with commentary: Anders, Jansen, and Reyes García
}

\section{RESUMEN}

Los nombres de muchos manuscritos pictóricos de la antigua Mesoamérica honran coleccionistas, políticos, o institutiones del mundo "occidental" o de la élite nacional, y son ajenos al pueblo que los creó y a la región a que refieren. Además los usos diferentes en designar estos códices y lienzos ya han introducido una confusión en la nomenclatura. Aquí proponemos una nueva serie de nombres, más en conformidad con los contenidos de los documentos y más cercanos a la cultura mesoamericana. Los pieles sagrados (ñee ñuhu) de Ñuu Dzaui (La Mixteca) son los códices Ñuu TnooNdisi Nuu (Bodley), Añute (Selden), Yuta Tnoho (Vindobonensis), Tonindeye (Zouche-Nuttall), Iya Nacuaa (Colombino-Becker/Caso), Nuu 
Ñaña (Sánchez Solís/Egerton), Ñuu Naha (Muro), Cochi con el Fragmento Nuu Naa (Becker II y Fragmento de Nochixtlan), Rollo de Yucu Yusi (Códice Tulane). El Grupo Teoamoxtli comprende los códices divi- natorios y rituales: Yoalli Ehecatl (Borgia), Tonalpouhqui (Vaticano B), Tlamanalli (Cospi), Tezcatlipoca (Fejérvàry-Mayer), Mictlan (Laud), Yada (Porfirio Díaz), Yecu (Fonds Mexicain 20), y Ciuacoatl (Borbónico).

\section{REFERENCES}

Anders, Ferdinand, and Maarten Jansen

1993 El Manual del Adivino. Libro explicativo del llamado Códice Vaticano B. Fondo de Cultura Económica, Mexico City.

Anders, Ferdinand, and Maarten Jansen (with a contribution by Alejandra Cruz Ortiz)

1994 Pintura de la muerte y de los destinos. Libro explicativo del llamado Códice Laud. Fondo de Cultura Económica, Mexico City.

Anders, Ferdinand, Maarten Jansen, and G. Aurora Pérez Jiménez

1992a Origen e historia de los reyes mixtecos. Libro explicativo del llamado Códice Vindobonensis. Fondo de Cultura Económica, Mexico City.

1992b Crónica mixteca: El rey 8 Venado, Garra de Jaguar, y la dinastía de Teozacualco-Zaachila. Libro explicativo del llamado Códice Zouche-Nuttall. Fondo de Cultura Económica, Mexico City.

1994 El Libro de Tezcatlipoca, Señor del Tiempo. Libro explicativo del llamado Códice Fejérváry-Mayer. Fondo de Cultura Económica, Mexico City.

Anders, Ferdinand, Maarten Jansen, and Luis Reyes García

1991 El Libro del Ciuacoatl. Homenaje para el año del Fuego Nuevo. Libro explicativo del llamado Códice Borbónico. Fondo de Cultura Económica, Mexico City.

1993 Los Templos del Cielo y de la Oscuridad: Oráculos y liturgia. Libro explicativo del llamado Códice Borgia. Fondo de Cultura Económica, Mexico City.

Anders, Ferdinand, Maarten Jansen, and Peter van der Loo (with contributions by Eduardo Contreras Martínez and Beatriz Palavicini Beltrán)

1994 Calendario de pronósticos y ofrendas. Libro explicativo del llamado Códice Cospi. Fondo de Cultura Económica, Mexico City.

Brotherston, Gordon

1995 Painted Books from Mexico. British Museum Press, London.

Burland, Cottie A.

1965 Codex Egerton 2895. Akademische Druck- und Verlagsanstalt, Graz.

Burland, Cottie A., and Gerdt Kutscher

1955 The Selden Roll. Gebr. Mann, Berlin.

Caso, Alfonso

1960 Interpretación del Códice Bodley 2528. Sociedad Mexicana de Antropología, Mexico City.

1964 Interpretación del Códice Selden 3135. Sociedad Mexicana de Antropología, Mexico City.

Glass, John B., and Donald Robertson

1975 A Census of Native Middle American Pictorial Manuscripts. In Handbook of Middle American Indians, Vol. 14, edited by Robert Wauchope, pp. 81-252. University of Texas Press, Austin.

Ixtlilxochitl, Fernando de

1975/77 Obras históricas. 2 vols. Universidad Nacional Autónoma de México, Mexico City.

Jansen, Maarten

1994 La Gran Familia de los Reyes Mixtecos. Libro explicativo de los llamados Códices Egerton y Becker II. Fondo de Cultura Económica, Mexico City.

1998 La Fuerza de los Cuatro Vientos. Los manuscritos 20 y 21 del Fonds Mexicain. Journal de la Société des Américanistes 84(2):125-161.

Jansen, Maarten, and G. Aurora Pérez Jiménez

2000 La Dinastía de Añute. Historia, literatura e ideología de un reino mixteco. Center of Non-Western Studies Research School of Asian, African and American Studies, Leiden.

2003 El Vocabulario del Dzaha Dzavui (Mixteco Antiguo), hecho por los padres de la Orden de Predicadores y acabado por fray Francisco de Alvarado (1593). Edición Analítica. Online publication: www.leiden.edu/faculty of archaeology/research. Native American Religion and Society/Middle America.

König, Viola

1979 Inhaltliche Analyse und Interpretaction von Codex Egerton. Beiträge zur mittelamerikanischen Völkerkunde XV. Hamburg.

León-Portilla, Miguel

1985 Tonalámatl de los Pochtecas (Códice mesoamericano "FejérváryMayer"). Celanese Mexicana S.A., Mexico City.

1996 Códice Alfonso Caso. La vida de 8-Venado, Gara de Tigre (Colombino-Becker I). Patronato Indígena, Mexico City.

Nowotny, Karl Anton

1961a Tlacuilolli, die mexikanischen Bilderhandschriften, Stil und Inhalt, mit einem Katalog der Codex Borgia Gruppe. Monumenta Americana. Gebr. Mann, Berlin.

1961b Codices Becker I/II. Akademische Druck- und Verlagsanstalt, Graz.

1975 El Fragmento de Nochistlan. Beiträge zur mittelamerikanischen Völkerkunde XIII. Hamburg.

Parmenter, Ross

1982 Four Lienzos of the Coixtlahuaca Valley. Dumbarton Oaks, Washington.

Smith, Mary Elizabeth

1973 The Relationship between Mixtec Manuscript Painting and the Mixtec Language. In Meso-american Writing Systems, edited by Elizabeth P. Benson, pp. 47-98. Dumbarton Oaks, Washington, DC.

1979 Codex Becker II: A Manuscript from the Mixteca Baja? Archiv für Völkerkunde 33:29-43.

1983 Codex Selden: A Manuscript from the Valley of Nochixtlan. In The Cloud People: Divergent Evolution of the Zapotec and Mixtec Civilizations, edited by Kent V. Flannery and Joyce Marcus, pp. 248 255. Academic Press, New York.

1994 Why the Second Codex Selden Was Painted. In Caciques and Their People. A Volume in Honor of Ronald Spores, edited by Joyce Marcus and Judith Francis Zeitlin, pp. 111-141. Anthropological Papers, Museum of Anthropology, University of Michigan 89. Ann Arbor.

2000 The Home Town of the Rulers of the Codex Muro. In In Chalchiuitl in Quetzalli, Precious Greenstone Precious Quetzal Feather, edited by Eloise Quiñones Keber, pp. 103-114. Labyrinthos, Lancaster, CA

Smith, Mary Elizabeth, and Ross Parmenter

1991 The Codex Tulane. Akademische Druck- und Verlagsanstalt, Graz, and Middle American Research Institute, Tulane University, New Orleans.

Troike, Nancy

1974 The Codex Colombino-Becker. Ph.D. dissertation, University of London.

Van Doesburg, G. Bas

2001 Códices Cuicatecos Porfirio Díaz y Fernández Leal. Grupo Editorial Miguel Angel Porrúa, Mexico City. 